\title{
Resisting Islamophobia: Muslims Seeking American Integration Through Spiritual Growth, Community Organizing, and Political Activism
}

\author{
Nazreen S. Bacchus
}

\begin{abstract}
Since 9/11, second-generation American Muslims have experienced an increase in religious discrimination that has presented several challenges to their social integration. Scholars have noted that Muslims are often marginalized and "othered" because of their religious beliefs, attire choices, and non-Western ethnic origins. Although Muslim communities are ethnically and racially diverse, they are categorized in ways that have transformed their religious identity into a racialized group. This new form of racial amalgamation is not constructed on underlying skin color similarities but on their religious adherence to Islam. This paper takes an intersectionality approach to understanding how Muslims across the New York metro area are managing their religious identities as they seek to develop a sense of belonging in American society. This ethnographic case study addresses how second-generation Muslims are resisting Islamophobia through community building, civic engagement, and college student associations. Countering Islamophobia has become part of everyday life experience for Muslims in New York and is currently their main trajectory for integration into American society.
\end{abstract}

Nazreen S. Bacchus is a Postdoctoral Fellow in the Sociology Department at Queens College, CUNY. Her research interests include qualitative methods, religious integration, and ethnic identification; recent publications include "Belonging and Boundaries in Little Guyana: Conflict, Culture and Identity in Richmond Hill, NY" (in Ethnicities) and "Shifting Sexual Boundaries: Ethnicity and Pre-marital Sex in the Lives of South Asian American Women" (in Sexuality and Culture). 


\section{Introduction}

June 26, 2018 marks the day the United States Supreme Court ruled in favor of the "Muslim Ban."' This legislation was initially introduced by President Donald J. Trump in an executive order signed into effect on January 27, 2017, barring the travel and entry of individuals from several Muslim majority countries into the US. In a 5-4 decision, the Supreme Court not only changed the lives of individuals with ancestral and geographical ties to the banned countries, but also validated the structural marginalization of Islam in America. Much as in the socio-political climate after 9/11, Muslims in the United States have been the direct targets of counterterrorism initiatives, especially surveillance and imprisonment, that have generated widespread fear and anxiety about the practice of Islam on American soil. ${ }^{2}$

The war on terror and surveillance of Muslim communities has intensified Islamophobic sentiments by categorizing Muslims as "suspects" and questioned their citizenship and sense of belonging in the United States. However, there is limited discussion of how Muslims are responding to overcome religious marginalization or the ways in which they are seeking religious inclusion in America. ${ }^{3}$ Much of the literature on Muslim integration in the United States, Canada, Australia, and in various European nations has shown how Muslim organizations serve to strengthen the voices of Muslim communities. ${ }^{4}$ Even within these studies, however, there is little discussion (if any) of how community building, civic engagement, and activist projects are grounded in religion. Since Muslims believe that Islam is a way of life, studying the intersections of how they use Islamic beliefs to resist discrimination and define a sense of belonging in America will provide much needed information about how Muslims are mobilizing not only to protect their religious freedom but also as a religious obligation.

My research seeks to fill the gap in the literature examining Muslim American integration by showing how American-born children of post1965 immigrants are resisting Islamophobic oppressions through community building, civic engagement, and activism projects. It does so through a multi-sited ethnography focusing on religious spaces, community events, political gatherings, and college campuses. I use an intersectionality framework to address the multiple layers of inequality shaping the lives of Muslim Americans and to show how Muslims are actively seeking to navigate and dismantle various forms of religious oppression. Through an ethnographic case study of adult, second-generation Muslim Americans, in this article I examine how this generation of rising Muslim community leaders are 
advocating for changes in social policies and institutions to accommodate Islamic needs in American society. I use the term resilient cititzenship to discuss their social responsibility in preserving and facilitating the integration of Islamic practices in the United States. They are not only extending the first-generation's efforts of maintaining diaspora religious communities but are also seeking to reframe the negative post-9/11 depictions of Islam and Muslims through community building, civic engagement, and activism.

Despite the discrimination they endure because of their faith, the young Muslims I spoke with showed a remarkable sense of resilience that was present in both their responses to Islamophobia and their attachment to Islam. Examining the complexitites that arise as Muslims resist Islamophobia will also shed light on the other forms of discrimination that are tied to their religious identities. This article shows that Muslim Americans are resisting not only religious discrimination but also the interlocking dimensions of gender, racial, and ethnic discrimination that intersect with their religious identities.

\section{Framing Muslim Identities in America}

Studies of Muslims in the United States ${ }^{5}$ have discussed the discrimination they endure through media depictions, social interactions, and public policies. Most of the current literature on post-9/11 Muslim American identities examines the multiple forms of racialized discrimination that Muslims are experiencing. The discussion of Muslim identification predominantly concentrates on the ways in which their citizenship and belonging have been negatively affected by Islamophobia in the United States. ${ }^{6}$ In particular, negative media depictions of Muslims and social policies specifically targeting Muslim communities including the Patriot Act, Handschu Agreement, and Muslim Ban on migration are the primary sources for developing stereotypes about Muslims. ${ }^{7}$ The war on terror has ultimately shifted the perceived identities of Muslims from hardworking immigrants and citizens to unassimilable and "foreign suspects." The research on the racialization of Muslim identities explains how these policies and the overarching acceptance of false claims about Muslims tends to dissolve the ethnic and racial diversity within Muslim communities. ${ }^{8}$ This is problematic because the acceptance of an "ideal-type" Muslim by wider American society has overshadowed the variation in race, ethnicity, nationality, and religiosity that exists in American Muslim communities. 
Missing from the literature on Muslim American experiences is a concrete analysis of how Muslim Americans are turning their encounters with discrimination into grassroots organizing projects aimed at achieving mainstream religious inclusion in American society. This theoretical gap in the literature contributes to the current framing of Muslim American life as one that is inundated with anti-Islamic experiences, instead of highlighting their perseverance to practicing Islam openly and freely on American soil.

Muslims use the process of community building to advocate for the respect of Islamic beliefs in American society. In terms of migration and group inclusion, Muslim immigrants and their American-born children are especially concerned with how their acceptance as Americans is challenged by the widespread negative depiction of Islam. The findings of this study indicate that second-generation Muslims in New York view the success of their American integration in terms of their ability to practice Islam in the presence of non-Muslims without controversy. With the increase in Islamophobia, Muslims in New York are rising up in resistance to the backlash against their faith. The intensified hate crimes, aggressive verbal attacks, and legislation controlling Muslim migration and surveilling Muslim communities in the US have all contributed to uniting the umma or community across ethnic and racial lines. The findings of my study shows how religious integration is a fluid process that involves various forms of community organizing within spaces of worship, civic engagement, and interfaith political activism. My contribution to the literature on immigrant integration sheds light on the new forms of diaspora and inter-ethnic organizing that occurs in response to discrimination. Muslim Americans are also engaging in grassroots interfaith organizing to inform non-Muslims about Islamic traditions in hopes of countering negative interpretations about their religion. It is important to acknowledge that my participants are mostly middle-class and are using their class position to empower Muslims across racial, ethnic, and class lines. Shedding light on how Muslim Americans are striving for local-level religious integration within their cities and communities is a step towards understanding how they are using local-level organizing to expand national religious recognition.

\section{Intersectionality and Muslim Life}

This project takes an intersectionality approach to understand the complexities of addressing Islamophobic discrimination and its role in shaping community building initiatives. Intersectionality scholars have found this framework useful in analyzing the multiple forms of complex inequalities 
shaping the lives of racialized minorities. ${ }^{9}$ Intersectionality has also been associated with the creation of "knowledge projects." ${ }^{0}$ These projects highlight the interconnectedness between power, discrimination, and social justice. Knowledge projects are central to connecting scholarship to community activism. Within the field of migration, intersectionality as a framework has the potential to show how newer immigrant groups are advocating for their right to practice their religious beliefs in America without interrogation or suspicion. There is a growing literature of intersectionality research that advocates for the inclusion of religion within this framework. ${ }^{11}$

In the case of Muslim Americans, several studies have shown that media constructions of "Muslims" are strongly tied to physical characteristics, including a brown skinned man wearing a beard or a woman wearing a headscarf. ${ }^{12}$ The framing of Muslims in America as "outsiders" or "unassimilable" since $9 / 11$ has created a sense of uneasiness among practitioners of Islam. ${ }^{13}$ This uneasiness stems from several sources including the unlawful surveillance of Muslim communities, negative daily interactions with non-Muslims who misunderstand Islam, social policies specifically targeting Muslims, and the charged political climate in the US. The backlash against Muslim American communities after 9/11 "led to the emergence of new leaders, especially among the second-generation who created new organizations to fill in existing gaps [in the community organizaing efforts of first-generation immigrants and native-born Muslim Americans]." ${ }^{14}$

This study provides a significant contribution to understanding how second-generation Muslim Americans are using their religious attachments in their struggle to gain respect for Islam in America. Spreading Islamic awareness is no longer restricted to $d a^{c} w a$ (proselytization) events. It is embedded into the daily practice of Islam, as the increased curiosity about Islamic rituals results in inquiries from non-Muslims seeking to understand the faith. Providing da'wa or informative knowledge about Islam is also a gendered process, in which men and women might receive different questions depending on their gender standpoint. In this light, Muslims have become activists in all spaces, whether socially visible or socially personal, due to the ways Islam is now practiced.

\section{Methodology}

I conducted this multi-sited research among adult, second-generation Mus$\lim$ Americans who were born to at least one immigrant parent, as myself a Muslim woman of Guyanese British Indian ancestry born in New York and 
an active participant in local Muslim community events. My position as an adjunct college professor and postdoctoral fellow also gave me a sense of status and helped to legitimize the nature of my research-especially at a time when Muslims in NYC are under NYPD surveillance. It was important for me to gain rapport not only as a Muslim and a community member but also a social scientist highlighting issues within the community. My entrée as a researcher began slowly in 2015, as I attended Muslim community gatherings and introduced myself to people. This research accelerated during the month of Ramadan in 2016, as multiple groups hosted events to break the fast.

In an effort to reach out to Muslims who do not attend community events, I posted a research call for in-depth interviews to Muslim listservs and on social media. I also conducted in-depth and informal conversational interviews with the participants I met during fieldwork. The total number of interviews, both in-depth and conversational, is 100 (40 men and 60 women). The data in this paper is based on the observations and accounts of twenty-eight Muslim men and forty women who identified as American born. I did not directly ask about citizenship but asked about birthplace. From this and their upbringing accounts, I determined their residency status. The observations and narrative accounts in this paper are based on interactions with those who identified as second-generation based on birthplace.

Although I had an insider perspective as a Muslim woman, my Caribbean ancestry was called into question by a few individuals who were only familiar with Hindu Indian Caribbeans and had never met a Muslim of Caribbean ancestry. Additionally, some of the Muslim sisters asked me if I was Muslim because I did not wear a hijab. These were the times when I felt like an outsider and had to explain my religious and ethnic position. It is also important to note that while this paper focuses specifically on immigrants, Blackamericans play a central role in the political organizing of Muslim communities in America. For example, in discussion of the Eid holiday, I address how immigrant groups often rally alongside Blackamericans for Islamic political inclusion. The majority of the respondents who participated in in-depth interviews are of Arab and South Asian descent. In my attendance at Muslim community events, I encountered and spoke with Muslims of various ethnic, racial, and class backgrounds. As an ethnographer, my goal is to convey the everyday life experiences of Muslim New 
Yorkers as they navigate their lives at a time when their faith and ethnicity are questioned in American society.

\section{Planting and Reaffirming the Seeds of Faith at Masjids and Islamic Centers}

Most of the masjids (mosques) in the New York metro area (New York, Connecticut, New Jersey, and Pennsylvania) began in converted spaces including storefront buildings or single family homes. Some masjids are actually former churches or synagogues that have been reconstructed into Islamic prayer spaces. Masjids in New York are the epicenters of immigrant and indigenous Muslim communities that function as spaces for uniting Muslims across ethnic, class, gender, and racial lines. Scholars have shown that newer immigrant groups often rely on religion as a source for reducing the anxiety and stress associated with cultural, linguistic and socio-economic integration into American society. ${ }^{15}$ According to several of my participants, their parents were the pioneers of building ethnic Muslim diaspora and Islamic community life in America. The Muslim brothers and sisters I spoke with repreatedly recounted their parents' efforts to connect with other Muslims who lived nearby. It was not enough for them to visit the houses of other Muslims, but there was also a significant need for a dedicated prayer space to build a sense of community. Their vision was to develop a space where Muslims could worship, learn about Islam, and strengthen their faith-especially in a country that introduced new values that often conflicted with their religious beliefs.

My participants who grew up in the 1980s and 1990s often described their childhood memories of being the "only Muslim family" or "one of the few Muslim families" in their neighborhood. Their parents' primary concern was raising their children "in the deen", or with strong Islamic faith. Most of my respondents were involved in the establishment of masjid communities alongside their parents. They all recalled participating in Islamic education and community-building projects during childhood and continue to be active members of masjid and Islamic center communities as adults.

Masjids and Islamic centers are not only places of worship and the accumulation of Islamic knowledge; they also provide a space for the second generation to interact with one another and develop both their American and Muslim identities. This is particularly important as both their Muslim and American identities are questioned by non-Muslim peers at school, 
work, or in public spaces. The use of these spaces also changes over time as the second generation grows from childhood into adulthood. In the interviews below, Saleh, Raeema, and Rose discuss the ways in which masjids and Islamic centers are used as fortresses against Islamophobia.

According to my interviews, many second-generation American Muslims in the New York metro area who grew up in ethnic communities were actively involved in their local masjid programs and events during childhood and continue to participate in what I term their "home masjids" in adulthood. All of my participants discussed the significance of masjid and Islamic center events in the development of their Muslim identities. Several participants mentioned that masjid communities were initially formed around faith, ethnicity, and common language. With the increasing migration of Muslim immigrants and rise in numbers of Muslim converts, most masjid communities have adopted English, instead of their ancestral language, as the primary language used during Friday sermons and other masjid lectures.

One of my male participants, Saleh, was the first to mention this form of migrant community-building during my interviews. Saleh is a twenty-five year old Pakistani American man who grew up in Connecticut and currently lives in New York. His local masjid was the focal point of his interactions with other Muslims in his community and a space where he could practice and learn more about Islam. Saleh's parents were among the first group of Muslims to settle in his neighborhood and pioneered the development of the nearby masjid. His mother was a community organizer who also taught Arabic, Qur'an, and Islamic Studies on the weekend in "madrassa" classes (also referred to as "Sunday School" or "Qur'an class" by several of my participants). The other Muslims in his masjid were from varying Arab and African backgrounds. As a child, he celebrated the diversity within the Muslim community; he discussed his appreciation for the ethnic and racial variation within his home masjid congregation. He had enjoyed spending time with the children in his masjid community because they shared a common faith and experience growing up in America.

Saleh's life outside of the masjid was filled with challenges at school about his faith and physical appearance. Living in a middle-class neighborhood placed his family in closer spatial proximity to white Americans. He attended elementary and high school with predominantly white American peers who openly expressed their ignorance about Muslims. During one of 
our conversations, Saleh mentioned a bullying incident that occurred after 9/11 in high school:

We were in high school playing a basketball game in gym. I got one of the guys out with the ball and he was upset about losing. He tried to chuck a basketball at my head in anger. I asked him "what's your problem?" and he [the bully] told me to "go back to Islam....you raghead and sand nigger." Those are racist terms used toward Arabs but now he was using it towards me-just because I'm Muslim. I ran towards him and punched him. I had to defend myself.

Saleh and his parents spoke with the principal about the incident and expressed their disappointment with the racial and religious bullying that he experienced. He served both detention and suspension for defending himself against the bully. The bully was also suspended. Neither student was expelled from school. Saleh's classmate used a game in gym class to express his racial frustration and masculine superiority. None of Saleh's classmates came to his aid during the confrontation. The negative statements made by Saleh's classmate not only questioned his religious and ethnic identities but also his social position or sense of belonging in America. Having dark skin and a Muslim name placed Saleh in the category of perceived outsider. The statement "go back to Islam" raises questions about how Islam is perceived by young non-Muslims and whether or not there is a shared sentiment that all Muslims should be expelled from America. Although Islam isn't a country, the words "go back to" are deeply rooted in a physical displacement or detachment from being perceived as an American.

His masculinity was also called into question during gym class as he struggled to defend both his sport position and his identity as a Muslim American man. Saleh's classmate expressed a form of hegemonic masculinity ${ }^{16}$ by claiming his superiority over Saleh's ability to get him out (and thereby win the game). Losing the game seems to have threatened not only his whiteness but also his manhood. Attacking Saleh based on his race, ethnicity, and religion allowed him to assert multiple forms of hegemony over Saleh. It appears that Saleh's classmate needed to regain control of his masculinity, which was challenged when he lost the game, by using negative comments and physical force to subordinate a Muslim man. Why did Saleh's classmate feel the need to attack his masculinity, ethnicity, and faith? The Muslim man is here perceived to have a weak form of masculinity; and directing negative sentiments toward this identity is a way of expressing social domination. 
This incident changed Saleh's life forever. From that moment forward, he became more aware of how his faith and appearance would be perceived by non-Muslims. He showed a remarkable resilience in responding to negative implications upon not only his ethnicity and religious identity but also upon his masculinity. Referring back to the second-generation's belief that Islam is a 'way of life', Saleh uses his religious connection as a means of resistance against discrimination. As an adult, Saleh recalls his own experience with discrimination in childhood as a source of motivation to become a community organizer and youth mentor. Saleh returns home on the weekend to visit his family and teaches Islam to children at the masjid. Although Saleh also attends other masjids closer to his home in New York for prayer and events, he is actively seeking to strengthen the community at his "home masjid." Engaging in discussions about racism and Muslim identities with youth is an important part of Saleh's activism and community building involvement. He openly shares his experience with other Muslims to provide a space where they can discuss their experiences with discrimination and learn how to cope with Islamophobia.

Muslim youth groups play a central role in the process of community building and spiritual growth in masjids and Islamic centers across New York. Community organizers who came of age in the post-9/11 era are now concentrating on raising the next generation of Muslims by helping them manage the discrimination they face. The youth groups also foster Muslim interactions outside of the masjid with planned recreational activities including ice skating, bowling, and picnics. Aside from peer counseling and recreational activities, Muslim youth groups in New York also host Islamic discussions and guest speaker panels to address social issues, including spiritual growth and Muslim identities.

In 2016 I met a young woman named Raeema at an informational event about Muslim mental health and wellness. While in conversation with her about contemporary social issues, she told me that the current negative discourse about Muslim Americans has had significant effects on their self-esteem-particularly the youth. Like Saleh, she decided to become a youth group organizer to address and reduce the potentially damaging effects that Islamophobia has on one's self-confidence and faith. As a middle-class college graduate from an American school, Raeema is using her experience of growing up in American society to teach younger Muslims how to navigate the challenges of young adulthood. 
In the academic literature, Islamophobia has been linked to directing young Muslims away from Islam because of the broadly negative media and peer perceptions of Muslims. Yet in these cases, second-generation Americans participating in Muslim youth groups are returning to Qur'anic scriptures and stories from the lives of the prophets to strengthen their resilience in facing present-day challenges of practicing Islam. In this light, the youth group serves as a reminder for young Muslims to stay connected to their faith as a means of overcoming challenges to their religious practice.

In addition to youth groups, adult lectures and community events also provide a space where young professionals can network and meet to discuss Islamic and secular social issues. As my participants aged out of their teenage years and transitioned into adulthood, they searched for spaces to interact with other Muslims among their peers. Many of them joined their college MSA (Muslim Students Association) but some were also interested in meeting Muslims off campus-especially after graduation. Rose, a young woman of Pakistani and white American background, recently moved to New York for employment and was eager to meet other Muslim professionals. Rose wears a turban-style hijab and is fair skinned. She discussed how her identity as a Muslim women is somewhat misunderstood.

People will tell me "oh your turban is so cute." When I tell them that I'm Muslim they say "oh, you're Muslim" and then look down [in embarrassment]. They think I'm wearing it for fashion or a trend. I work in the fashion industry so I can see why it might be misunderstood, but it's part of my religious identity-even though I don't wear a hijab like a hijab [meaning the wrapping style of hijab that covers the neck].

As a light-skinned, mixed-race woman, Rose is often perceived as racially white. Her turban-style hijab and fair complexion do not make her visibly Muslim. Her femininity as a Muslim woman is then subordinated by hegemonic forms of white femininity, ${ }^{17}$ particularly in American fashion trends that view turban headwraps as trendsetting and chic. In my field observations, I noticed that some Muslim American women are using the turban style to maintain hijab and protect their modesty without wrapping the fabric around both their head and neck. Their choice to cover their hair with a turban is a personal decision that reflects their own practice of (and relationship with) Islam. This perception of Rose's hijab as "trendy" ignores her intentions to wear this fabric as part of her religious obligation and places her femininity within a secular sartorial framework. There is a growing body of intersectional research ${ }^{18}$ that points to the need to examine 
different forms of non-white femininities while challenging hegemonic white femininity. However, these studies largely lack an analysis of the role of hegemonic femininity in religious identification. Although Rose wears a turban-style hijab, she is often perceived as white and not Muslim. Instead of passing as trendy or white, Rose uses these assumptions about her identity to inform people about Islam. It can be an opportunity to spread $d a^{c} w a$ or religious awareness and to use her religious belief to resist this type of misrecognition or outright discrimination.

Living a far distance from her immediate family members, Rose relies on masjids and Islamic centers in New York City for spiritual and social comfort. She frequently attends programs and events at an Islamic center in NYC that attracts a young, millennial community. When facing issues of discrimination, particularly related to her style of dress or hijab, Rose enjoys meeting her friends at the center so that she can discuss any concerns about her Muslim American identity and engage in social activities with friends of the same faith. The center also has a woman's group that hosts monthly brunches, picnics, and religious gatherings centered on creating a Muslim sisterhood. Community members are involved in multiple projects at the center including Islamic studies, community service, and interfaith initiatives. The young professionals who are members of this Islamic community play a pioneering role in introducing new ways of building a strong Muslim community. The leaders of this center are concerned with bridging the gap between social issues and Islam for its young congregation. Hosting events on topics such as political mobilization, domestic violence, mental health, and Islamophobia provides a much needed space for young Muslim Americans to learn how to cope with various social conditions. The center also provides mentorship, networking events, and Islamic classes that are centered on reconnecting with Islam.

Community building at masjids and Islamic centers in New York is a multifold process that is centered on spreading Islamic awareness and faith renewal. These processes are central to the religious framework of building institutions that address and manage discrimination. Second-generation Muslims are defining new ways of organizing in masjid and Islamic center spaces by discussing religious discrimination and connecting it to the need to strengthen both their American and religious identities. In an era of Islamophobia, Muslims of all ages, races, and national origins are seeking out ways of strengthening their connection to faith as a means of coping with discrimination. Community building provides a fortress against the 
negative interactions and sentiments directed towards Muslims and their practice of Islam. The second-generation masjid and Islam center coordinators routinely quote verses from the Qur'an and the life of the Prophet to guide community members toward the healing properties of Islamic scriptures. In this light, Islamophobia is actually motivating Muslims towards their faith instead of pushing them away from Islam.

\section{Civic Engagement: A Pathway for Ethno-Religious Recognition and Community Building}

Second-generation Muslim New Yorkers are significantly involved in political activism and civic engagement. ${ }^{19}$ Engaging in electoral politics and grassroots activism is particularly significant to Muslim American communities after 9/11. During the 2016 Presidential campaigns, the negative spotlight on Muslim Americans elevated the racialization that Muslims have been enduring under the war on terror. These negative sentiments have ignited a flurry of grassroots political campaigns in support of pro-Muslim candidates. Although several of the 2016 presidentital campaigns highlighted misconceptions and false claims about Islam, this was a moment where Muslim Americans' resilient citizenship became exceptionally salient. Democratic candidate Bernie Sanders was instrumental in building a pertinent platform by including Muslim community leaders at his campaign rallies and featuring women in hijabs in the background of his press conferences. Recognizing Muslims as American citizens and constituents with voting power, Bernie Sanders was able to bring Muslim communities to the center of national electoral politics. ${ }^{20}$

According to my observations, Muslim involvement in political campaigns for local elected officials and motivation to "get out the Muslim vote" on election day-particularly since 2015-speaks volumes about their inclusion in New York politics. Unlike the first-generation immigrants who were concerned with developing transnational immigrant diaspora communities, ${ }^{21}$ the second-generation community members I interacted with take the development of immigrant community life a step further by positioning themselves as community liaisons within various NY elected official and government offices. Based on my observations, members of the community's first generation are also becoming more politically active, though in different ways. The first-generation elders are more likely to play a role in welcoming elected officials to the masjids to learn more about Islam or tour the property. Candidates running for local elected offices, whether Muslim 
or non-Muslim, are also invited to speak about their community service at the masjids during Friday Juma prayer. However, the first-generation community members still seem to remain at a distance from grassroots political activism and campaigning efforts for local officials.

By and large, second-generation Muslim Americans are more likely to engage in direct campaigning efforts for candidates running for elected office than their first-generation counterparts. This is particularly important because candidates running for elected office need to secure their votes to win their desired seat and are willing to work with constitutents on the issues important to them. Elected officials seeking the Muslim vote use various methods of reaching out to Muslim community leaders. Some ask to visit masjids and speak directly to Muslim congregations, while others invite young community leaders to act as spokespeople who represent their campaign and present their agenda to the Muslim community. Both methods are used to accrue votes but the second method is also used to gain campaign volunteers. When spokespeople or well-recognized and respected community leaders align themselves with a particular candidate, they are looking for members of the Muslim community to not only vote for the candidate but also to become involved with the campaign.

I attended my first phone banking event right before the democratic primary election in 2016. A group of community leaders who were involved in political activism organized a meeting in a conference room located inside an office building in NYC. As I entered the conference room, I noticed that the table was designed with electrical oulets embedded into the wood at the center of the table. There were about twenty people at this phone banking event. Most of them were community organizers. Only about two of these attendees were not community organizers and were first time attendees-whom I never saw again during my fieldwork. The meeting began at around 7:30pm and attendees immediately plugged in their laptops and phones into the table outlets. The organizers had a special website and detailed log-in information that they provided us alongside the telephone numbers of people who could potentially vote for Bernie Sanders. Before the phone banking began, one of the organizers provided a brief introduction and spoke about the significance of securing the rights of Muslim Americans by teaming up with elected officials. I brought my iPad and cell phone but was unable to connect to the website. Instead of making calls, I watched the others as they called and spoke to complete strangers on the other line, encouraging them to vote for Bernie. No one identified 
as Muslim when they informed the call recipient about the nature of their call. Yet, the regular club members showed dedication to helping his campaign - particularly because he welcomed Muslims into his campaign and provided them with a platform to voice their concerns at campaign rallies.

Each one of the phone bankers eagerly participated in Bernie's campaign. Volunteering for Bernie not only symbolized their excitement about his recognition of Muslim Americans' religious freedom during his campaign rallies; they also wanted to be a part of remaking America. The organizers viewed the religious inclusion of Muslims in political campaigns as an opportunity to be recognized as an "American." They were also concerned about the way in which Donald Trump's campaign intensified anti-Muslim sentiments and wanted to secure an opposing candidate that would counter his negative depiction of Muslims.

Second-generation Muslim Americans in NY are actively participating in local politics. According to Pew Research, seventy percent of Muslim Americans are US citizens; my data shows that they have a significant and visible political presence in NY. Most of my participants mentioned that grassroots organizing efforts begins in immigrant communities. Several of my respondents initially grew up in working class families that gained middle-class status overtime. They participated in building their immigrant communities from the ground up-even as their working families had limited resources. Migration plays a significant role in the ways second-generation Muslim Americans view their social position in America. Similar to other studies in which the children of immigrants feel indebted to their parents and families for migrating to America, ${ }^{22}$ the participants in this study view their American identities within a framework that recognizes their ties to their ethnic communities. Second-generation Muslims in New York are rising community leaders and are focusing on developing and maintaining their immigrant communities. Several of the immediate post-1965 first-generation community builders are aging out of their leadership roles. Most of the next wave of Muslim American leaders are either the children of former organizers or those who are actively striving to begin new ventures and community partnerships that meet their integration needs. This is particularly important as Muslim communities are working across racial, ethnic, and class lines to spread Islamic awareness and resist Islamophobia in American society.

Second-generation Muslim Americans are especially concerned about their constitutional right to practice Islam. In 2013, about seven 
second-generation Muslim Americans who recently graduated college and graduate school used their educational backgrounds to begin a pioneering political organization to increase Muslim Americans' civic engagement. These young professional, middle-class Muslims working in legal, non-profit, and government positions in NYC united together to establish The Muslim Political Collective. ${ }^{23}$ This club was designed to endorse candidates, address issues in Muslim ethnic communities, and most importantly, organize like-minded Muslims in an effort to increase their civic engagement in New York. Most of the club meetings take place in office spaces and meeting rooms. Approximately 30-40 people are present at each of the monthly meetings and are of different races and ethnicities, including Pakistani, Guyanese, African, Blackamerican, White American, Palestinian, Egyptian, Chinese, and Bangladeshi. Akbar, a member of the Collective, commented:

The club is a really grassroots effort put together by Muslims interested in social justice and working with elected officials to do so. We have meetings at least once a month and invite elected officials to speak at our events. Muslims from all over NYC are part of the group and we even have some members from the suburbs.

According to my interviews and observations, one of the most influential campaigns that the club supported was the passage of Eid in New York City, where they advocated alongside elected officials and Blackamerican Muslim leaders in NY to promote the closing of public schools on Eid holidays. The Eid holidays were actually first recognized under the administration of former Mayor Dinkins in 1992. During that time, the Department of Transportation suspended alternate side parking throughout NYC to make parking easier for Muslims going to Eid prayer. ${ }^{24}$ Rallying for the closure of NYC public schools on the Eids seemed like the logical next step. The club leaders mentioned that Muslim students ended up taking the day off from school. Parents I spoke with were concerned about their children missing class and exams. The Eid holidays have important significance within Islam and parents are concerned about their children's practice of Islam in America. Most favored allowing their children to miss a day of school, while others were concerned about their children's academic performance if they missed class. With the recent increase in the Muslim population attending NYC public schools, community leaders began petitioning for the recognition of Eid holidays on the public school calendar. The City Council approved the Eid holiday school closure during former Mayor 
Bloomberg's administration, but this proposal was vetoed by Bloomberg who stressed the separation of church from state. ${ }^{25}$ Club members and Muslim community leaders were disappointed about the veto but saw their next opportunity to introduce the school holidays during Bill DiBlasio's mayoral campaign. According to my interviews and observations, the Eid in NYC campaign was a landmark decision that highlighted the inclusion of Muslim Americans not only as New Yorkers but as a key demographic in NYC politics.

This was a family effort. "My nieces [in public school] were even in the campaign," stated one of the women at the forefront of the movement. The holidays were successfully included in the New York City public school calendar beginning in the 2015-16 academic year. This policy victory signified a moment of resilience for the Muslim Americans engaged in the campaign. After campaigning for years and enduring the rescinding of the public school holidays during the Bloomberg administration, these Muslims' resilient citizenship is strongly tied to their advocacy for Islamic rights. The second generation's strong attachment to political inclusion is their method of gaining structural acceptance and recognition of Islamic religious performances. This religious advantage is a product not only of their efforts to successfully create a political club that serves Muslims in NY, but also of their ability to forge alliances with Blackamerican Muslims who have been politically active for decades. Again, the members of the Muslim Political Collective are using their belief in Islam as a way of life to gain structural intregation of Islam through local policy changes that accommodate their religious needs. Muslim Americans' political integration is strongly tied to their constitutional right to practice Islam openly and freely in America.

The political and activist institutions developed by the second generation provide vital resources to Muslim New Yorkers who are experiencing religious inequality and are seeking legislative changes that protect their Islamic beliefs. They are actively resisting challenges and are working with elected officials to amplify their voices in both state and nationwide legislative sessions. Although second-generation Muslims in New York are concerned with upholding and protecting their transnational ties, their political priorities seem to lie in securing and maintaining religious freedom in America. 


\section{Spreading Islamic Awareness: The Role of Campus Muslim Student Associations}

College Muslim Student Associations (MSAs) play a central role in shaping the lives of Muslim young adults. About $85 \%$ of Muslims in this study are enrolled in or graduated from public colleges in New York City. Most of the second generation are from working and middle-class families, attending public colleges. About $15 \%$ of the participants are currently enrolled in or graduated from private and parochial affiliated colleges and universities. Across these differences, the majority of participants were either regular members or attended MSA events occasionally-even after graduating. There were a few respondents who were either not interested in participating with their campus MSA or had work and family commitments that prevented their attendance at meetings and social gatherings. MSAs are designed to unite Muslims across ethnic, racial, gender and class lines and are one of the earliest Islamic institutions developed by post-1965 immigrants. ${ }^{26}$ Middle-class students are more likely to occupy leadership roles in the MSAs that I studied. Working-class Muslims participate in MSA events but are not as active in planning events or attending them because of their work schedules. MSAs have recently begun livestreaming their public lectures to accommodate scheduling conflicts.

In a post-9/11 society, MSAs are more than just the religious revivalist organization that first-generation (post-1965) Muslim immigrants initially envisioned. ${ }^{27}$ While the organization's platform is still connected to politics, MSAs are centered on raising awareness about both national issues and transnational ones from across the Muslim umma. Devleoping their Muslim and Islamic identitities is at the center-stage of their mission but they are also addressing questions related to Islamophobia, gender, and interfaith interactions. Spreading Islamic awareness to both Muslims and non-Muslims requires strategic planning of activities and bi-monthly discussions throughout each academic semester. Lectures held by invited speakers are usually held during common hour or club hour on campus. These events are mostly attended by students on campus but are sometimes frequented by alumni and other Muslims who are interested in the topic. Evening events are usually open to attendance by the entire Muslim community (students and non-students) and the invited speaker is either a notable scholar, imam, or sheikh. ${ }^{28}$ In this light, events are organized by the middle-class students who have the resources and network connections to invite and host notable speakers. They are using their class privilege to 
benefit the entire Muslim community by publicly posting about their events on group chats and social media sites. Thus, MSA events are benefitting not only students attending the college or university but also the wider Muslim community in New York.

Speakers are selected not only on the basis of their prominence within the Muslim community but also for their area of specialization within both the religion and in their Islamic awareness outreach. The New York metro area is privileged in that regard because so many of the internationally-known Muslim community organizers are based locally. This not only facilitates the ability for MSAs to draw on a variety of knowledgable community leaders but also places them in a position to strengthen their resilience to Islamophobia. There are an abundance of talks occurring at various universities throughout the academic year. Speakers normally repeat their presentations at different campuses; since these events are open to the public, Muslims in New York have the convenience of choosing from among these event options.

In fall 2015, a well-known, New York-based imam was invited to speak about the rise of Islamophobia and its implications for Muslims in American society and globally. Although the discussion mentioned the ways in which Muslims have been received by American society since 9/11 and the increase in hate crimes and prejudice against Islam, the talk focused more on using examples from the life of the Prophet Muhammad (peace be upon him) and Quranic verses to understand Islamophobia. "What would the Prophet (peace be upon him) do?" is a question that helps guide Muslims to think clearly about how to manage the hurt and pain they feel when faced with Islamophobia. Engaging in prayer, reflection, and seeking out social networks with other Muslims are the means by which the imam encouraged the attendees to navigate these difficult times.

The framing of issues affecting Muslims in American society is key to organizing as a group and bridging the gap between those who are open to being politically involved and others who tend to shy away from it. Political involvement is also subjective: one might view a conversation about Islamophobia as a political discussion while others might view it as a means of defending one's religious beliefs devoid of a political agenda. In a campus environment, Muslim students, graduates, and event attendees have the advantage of choosing the way in which they personally identify with their interpretation of what Islamophobia means. The second-generation Muslim American organizers of this event were concerned about the rise in anti-Muslim sentiment occurring in 2015 around the nation and decided 
to invite the imam to motivate students to practice Islam despite the rise in Islamophobia. Placing Islamophobia into the context of Islamic history and highlighting the stories of various prophets is a way of emphasizing religious resilience in the wake of increasing discrimination.

Another way in which the MSA contributes to contouring Muslims' resilient citizenship is the celebration of "Islam Awareness Week" on campuses across New York and the United States. The MSAs dedicate one week during the semester to showcasing Islamic rituals and cultures to non-Muslim students on campus. "Hijab for a day," "Jumu'a on the lawn," and open forums on Islamic teachings and Islamophobia are some of the many ways in which young adult Muslims are using the campus environment to make Islam and Muslim identities part of the American mainstream. As a group, the MSA represents Muslim identities on college campuses. They are aware that "irrespective of generation, religiosity, and national origins, the events of 9/11 put the onus on Muslims to reassess their collective presence..." 29 Reaching out to non-Muslims is an opportunity to reframe the narrative of Muslim identities by clarifying misconceptions about Islam.

According to my interviews, "Hijab for a day" was a particularly successful event on college campuses. Non-Muslim women have the chance to try on a hijab or headscarf and learn how to wrap the scarf in fashionable ways. They learn the Islamic significance of wearing a headscarf and contemporary ways in which Muslim women do so. "Hijab for a day" became a symbol of solidarity with Muslim women and a means of respecting their religious traditions as part of their American identities. Although the Muslim college women I spoke with were eager to discuss the significance of hijab and distribute scarves to their non-Muslim peers on campus, they were concerned about how other students would internalize their effort to demonstrate their resilience against religious garment discrimination.

Some of the Muslim women I spoke with were concerned with varying perceptions of headscarves. One college woman I interviewed, Jameena, discussed her disappointment with people who interpret the hijab differently when worn by non-Muslim and Muslim women. She mentioned that non-Muslim women are associated with wearing a headscarf as a "trendy piece of fashion but on Muslim women, it is perceived as different, foreign or even oppressive." On the other hand, non-Muslim women wearing a headscarf might not be considered chic. They might actually face stigma for supporting Muslim women's religious rights. For example, former Wheaton College professor Larycia Hawkins, a Christian woman, wore a hijab on campus to symbolize solidarity with Muslim women during 
advent season-and in doing so sparked a controversy which ultimately made mainstream media headlines. As a Christian, Dr. Hawkins viewed Muslim women as "people of the book" and wore the hijab to showcase their common origin and history. ${ }^{30}$ Unfortunately, her choice to support the religious inclusion of visibly Muslim women was met with criticism from students, faculty, and other public figures, eventually leading to her leaving the college.

The act of wearing a headscarf for religious portrayal continues to be a site of contention. The young women who are involved in organizing events about hijab awareness are hopeful that introducing the practice to non-Muslims, will, at least, result in awareness if not acceptance of their right to practice their Islamic beliefs.

\section{Discussion}

In the years following 9/11, Muslim Americans have shown their resilient citizenship by strengthening their community building, civic engagement, and Islamic awareness advocacy. The negative media attention directed at Islam and Muslim identities has placed them at the forefront of defending their religious freedom. The American-born children of post-1965 immigrants have a strong attachment to both their American birthright and Islamic beliefs. Since 9/11, their attachment to both Islam and America has been under attack. Policies directed at the policing and control of Muslim communities have marginalized them under the labels of "suspect" or "terrorist." The Muslim Ban has taken this a step further by restricting the migration of individuals from five predominantly Muslim nations.

Resisting these labels is tied to a process of recovering from multiple forms of racialization and marginalization. This type of resilient citizenship is particularly noticible among middle-class, second-generation Muslim American community leaders who are pioneering new forms of religious rights advocacy within their communities. They are taking the community building skills learned from earlier post-1965 immigrants, their parents' generation, and developing nuanced approaches that are uniting Muslims across racial, ethnic, gender, and social class backgrounds. Building from the creation of transnational diaspora religious communites engaging in Islamic revival, second-generation Muslims are integrating these concepts into a movement that is aimed at reframing Muslim identities. The negative sentiments and misconceptions about Islam that are widely accepted by non-Muslims across the nation have motivated the ways that the second generation are approaching American integration and religious inclusion. 
By creating spaces where Muslims can discuss their experiences with Islamophobia and learn strategies for coping with discrimination, the second generation is learning to address how discrimination affects them as individuals and as a community.

Political activism and civic engagement are important ways that the second generation are advocating for religious inclusion. Whether it is the recognition of Eid holidays or political campaigning, Muslim Americans are using their voting power to communicate their religious concerns to elected officials. This is another strategy of inclusion started by earlier Muslim activists but was not widely accepted by first-generation immigrants until after 9/11. This is a particularly significant contribution of the children of Muslim immigrants within their ethnic communites because they are using strategies of political inclusion practiced by Blackamerican Muslims in the Civil Rights era to secure the rights of newer Muslim groups. Muslims working alongside elected officials as community liaisons provide a much-needed voice and platform to convey issues related to discrimination, diversity, and inclusivity. Garnering political support from elected officials is important to securing and protecting Muslim Americans' constitutional right to practice Islam.

Lastly, the second generation is providing Islamic awareness advocacy on college campuses across New York. College campuses are sites of information exchange, cultural diffusion, and activism. College students are at a crossroads of exploring their own identities and interacting with students from diverse backgrounds. MSAs are taking advantage of this campus opportunity to introduce Islamic practices (including prayer and hijab) to their non-Muslim peers. Aside from giving $d a^{i} w a$, this is also a moment where Muslim students are building and strengthening their faith in Islam on their campuses. Members of the MSA are building their campus communities by hosting Islamic events that address their faith-based needs and introduce Islam to non-Muslims. Hosting lecture discussions about discrimination and Islamic history allows students to express their concerns about their Muslim identity and frame their coping mechanisms within a religious context. Expanding on the original revivalist agenda behind MSAs, newer group leaders are using the role of this campus organization to engage in interfaith discussions and to increase the conversations about religious diversity on campus.

Overall, second-generation American Muslims are developing their own social institutions and networks to advocate for their religious inclusion. This case study of Muslim activism and community building in New 
York sheds light on their determination to protect their religious freedom and overcome the negative sentiments and misconceptions about Islam. The pioneers of this movement are continuing to expand their networks with Muslims across the nation and with non-Muslims who are advocating for Muslim rights. Further research is needed to track the effects of the Muslim Ban on the migration of Muslim groups and the transnational connections that are maintained. Community organizers in New York are continuing to rally for the religious inclusion of Muslims in American society. Their efforts have been well received in local level politics-yet they are striving for national religious inclusion.

\section{Endnotes}

1. My respondents used the term "Muslim Ban" instead of the actual name ("Executive Order Protecting the Nation from Foreign Terrorist Entry into the United States") because the initial legislation specifically targeted foreign nationals from seven Muslim majority nations from visiting the US and permanently banned Syrian refugees. Although North Korea and Venezuela are were also included on the list, the migration ban clearly targeted Muslim-majority nations.

2. Moustafa Bayoumi, How Does It Feel to Be a Problem? Being Young and Arab in America (New York: Penguin Books, 2009); Moustafa Bayoumi, This Muslim American Life: Dispatches from the War on Terror (New York: New York University Press, 2015); Junaid Rana, Terrifying Muslims: Race and Labor in the South Asian Diaspora (Durham: Duke University Press Books, 2011); and Sunaina Marr Maira, Missing: Youth, Citizenship, and Empire after 9/11 (Durham: Duke University Press Books, 2009).

3. Khaled Beydoun, American Islamophobia: Understanding the Roots and Rise of Fear (Oakland: University of California Press, 2018); Deepa Iyer, We Too Sing America: South Asian, Arab, Muslim, and Sikh Immigrants Shape Our Multiracial Future (New York: The New Press, 2015).

4. Renae Barker, State and Religion: The Australian Story (New York: Routledge, 2018); Roksana Nazneen, "Bangladeshi Muslims in Montreal: A Case of Divided Loyalty," International Journal of Sociology of the Family 31, no. 2 (2005): 109-22; Stephen H. Jones, "The 'Metropolis of Dissent': Muslim Participation in Leicester and the 'Failure' of Multiculturalism," Ethnic and 
Racial Studies 38, no. 11 (2015): 1969-85; Aleksandra Lewicki and Therese O’Toole, “Acts and Practices of Citizenship: Muslim Women's Activism in the UK," Ethnic and Racial Studies 40, no. 1 (2017): 152-71; Bayoumi, How Does It Feel to Be a Problem?

5. Bayoumi, This Muslim American Life; Madhulika S. Khandelwal, Becoming American, Being Indian: An Immigrant Community In New York City (New Delhi: India Research Press, 2004); Maira, Missing; Rana, Terrifying Muslims.

6. Maira, Missing; Beydoun, American Islamophobia; Bayoumi, This Muslim American Life.

7. Beydoun, American Islamophobia; Saher Selod and David G. Embrick, "Racialization and Muslims: Situating the Muslim Experience in Race Scholarship," Sociology Compass 7, no. 8 (August 2013): 644-55; Bayoumi, This Muslim American Life; Iyer, We Too Sing America.

8. Rana, Terrifying Muslims; Bayoumi, This Muslim American Life; Zareena Grewal, Islam Is a Foreign Country (New York: New York University Press, 2014); Muna Ali, Young Muslim Americans: Faith Community, and Belonging (New York: Oxford University Press, 2018).

9. Patricia Hill Collins, "Intersectionality's Definitional Dilemmas," Annual Review of Sociology 41 (2015): 1-20; Bandana Purkayastha, "Intersectionality in a Transnational World," Gender \& Society 26, no. 1 (2012): 55-66.

10. Collins, "Intersectionality's Definitional Dilemmas."

11. Purkayastha, "Intersectionality in a Transnational World."

12. Bayoumi, This Muslim American Life; Bayoumi, How Does It Feel to Be a Problem?; Rana, Terrifying Muslims; Maira, Missing; Shabana Mir, Muslim American Women on Campus: Undergraduate Social Life and Identity (Chapel Hill: The University of North Carolina Press, 2016); Iyer, We Too Sing America.

13. Rana, Terrifying Muslims; Bayoumi, This Muslim American Life; Maira, Missing.

14. Anny Bakalian and Mehdi Bozorgmehr, Backlash 9/11: Middle Eastern and Muslim Americans Respond (Berkeley: University of California Press, 2009). This is particularly important because Muslim identities and the framing of Islam has shifted several times since September 11, 2001.

15. Khandelwal, Becoming American, Being Indian; Pyong Gap Min, Preserving Ethnicity Through Religion in America: Korean Protestants and Indian Hindus Across Generations (New York: New York University Press, 2010); Jana Evans Braziel and Anita Mannur, eds., Theorizing Diaspora: A Reader (Malden, MA: Wiley-Blackwell, 2003); Prema A. Kurien, "Being Young, Brown, and Hindu: The Identity Struggles of Second-Generation Indian Americans," Journal of Contemporary Ethnography 34, no. 4 (August 1, 2005): 434-69; Prema Kurien, "Gendered Ethnicity: Creating a Hindu Indian Identity in 
the United States," American Behavioral Scientist 42, no. 4 (January 1, 1999): 648-70.

16. R.W. Connell, Masculinities, 2nd ed. (Berkeley: University of California Press, 2005). Connell uses the term 'hegemonic masculinity' to discuss the ways in which expectations of white men's masculinity are enforced through cultural norms as the dominant form of masculinity.

17. Karen P. Pyke and Denise L. Johnson, "Asian American Women and Racialized Femininities: 'Doing' Gender across Cultural Worlds," Gender \& Society 17, no. 1 (February 2003): 33-53.

18. Pyke and Johnson, "Asian American Women and Racialized Femininities"; Yen Le Espiritu, “We Don't Sleep Around Like White Girls Do’: Family, Culture, and Gender in Filipina American Lives," Signs: Journal of Women in Culture \& Society 26, no. 2 (Winter 2001): 413; Emir Estrada and Pierrette Hondagneu-Sotelo, "Intersectional Dignities: Latino Street Vendor Youth in Los Angeles," Journal of Contemporary Ethnography 40, no. 102 (2011); Patricia Hill Collins, Black Feminist Thought: Knowledge, Consciousness, and the Politics of Empowerment (New York: Routledge, 2000).

19. Bakalian and Bozorgmehr, Backlash 9/11.

20. Nick Corasaniti, "Bernie Sanders Warns of Demagogues and Divisions in Mosque Visit," The New York Times, December 16, 2016, https://www.nytimes.com/politics/first-draft/2015/12/16/bernie-sanders-warns-of-demagogues-and-division-in-mosque-visit/; Kayla Epstein, "Muslim Advocates Welcome Bernie Sanders' Support but Want Visible Action," The Guardian, November 2, 2015, https://www.theguardian.com/us-news/2015/nov/02/ muslim-american-groups-bernie-sanders-islamophobia.

21. Grewal, Islam Is a Foreign Country.

22. Philip Kasinitz et al., Inheriting the City: The Children of Immigrants Come of Age (Cambridge, MA: Harvard University Press, 2008); Alejandro Portes and Rubén G. Rumbaut, Immigrant America: A Portrait, 3rd ed. (Berkeley: University of California Press, 2006).

23. This is a pseudonym.

24. "Parking Made Easier On 2 Muslim Feasts", The New York Times, September 22, 1992, https://www.nytimes.com/1992/09/22/nyregion/parking-madeeasier-on-2-muslim-feasts.html.

25. "Muslims Seek to Add Holidays on NY School Calendar," Reuters, July 12, 2010, https://www.reuters.com/article/us-usa-religion-newyork-islam/muslims-seek-to-add-holidays-on-ny-school-calendar-idUSTRE66B62Z20100712.

26. Grewal, Islam Is a Foreign Country.

27. Grewal. Islam Is a Foreign Country, 140-145.

28. Non-Muslim attendees are also invited to these events but usually attend in small numbers. 
29. Bakalian and Bozorgmehr, Backlash 9/11, 222.

30. Ruth Graham, "The Professor Wore a Hijab in Solidarity - Then Lost Her Job," The New York Times Magazine, October 13, 2016, https://www.nytimes. com/2016/10/16/magazine/the-professor-wore-a-hijab-in-solidarity-thenlost-her-job.html. 